\title{
Suspending the 'lack' through art: African and western epistemological and artistic intersections (Mia Couto, Wole Soyinka, Léopold Senghor, Gaston Bachelard and Mark Epstein)
}

\section{Irene Marques}

To cite this article: Irene Marques (2018): Suspending the 'lack' through art: African and western epistemological and artistic intersections (Mia Couto, Wole Soyinka, Léopold Senghor, Gaston Bachelard and Mark Epstein), African Studies, DOI: 10.1080/00020184.2018.1426310

To link to this article: https://doi.org/10.1080/00020184.2018.1426310

曲 Published online: 22 Jan 2018.

Submit your article to this journal ¿

Q View related articles ¿

View Crossmark data $₫$ 


\title{
Suspending the 'lack' through art: African and western epistemological and artistic intersections (Mia Couto, Wole Soyinka, Léopold Senghor, Gaston Bachelard and Mark Epstein)
}

\author{
Irene Marques
}

University of Toronto

\begin{abstract}
As a continuation of my previous transcultural project, the current study aims to unearth some other similarities that exist between African classical knowledge systems, as put forward in the writing of Mia Couto and the work of other Africanists such as Wole Soyinka, Jacob Olupona and Léopold Senghor - in respect to their links to poetic speech and relational, holistic and mystical epistemologies - and the ideas defended by some western critics such as Mark Epstein, Gaston Bachelard, John Fox, and Mark Greene, in relation to the powers of poetic language (or art in general) and the search for knowledge, holism, and existential realisation. The central argument here is that poetry and creative writing have the function of powerful therapies, serving as tools that allow a holistic apprehension of life, a figurative entrance into and recreation of the 'cosmic envelope' and in that sense, are very much associated with relational and holistic African traditional ways of understanding self and universe. Thus, it is argued that both of these processes have a sublimating function serving to disrupt human fragmentation and temporarily (and symbolically) suspend the 'lack' (incompletion and loneliness) that most (if not all) humans are bound to feel.
\end{abstract}

\section{KEYWORDS}

African systems of knowledge; lack; cosmic envelope; art; relational; holism; Mia Couto; Wole Soyinka; Léopold Senghor; Mark Epstein; Gaston Bachelard

I left my body and I was only eyes and mind, that's all, she says. I could think and I could see. I didn't try to speak because I was so fascinated with this experience. The attraction! Ooh, it was better than anything I'd ever felt. It was free, it was intelligent and I was in control. And the only other time that happens - those three things - is when I write. ${ }^{1}$

What moves me is the divine vocation of the word, which not only names but invents and produces enchantment. (Couto 2009: 14) ${ }^{2}$

In my other scholarly critical work (Marques 2011, 2015a \& b, 2016) on Mia Couto I have advanced the argument that Couto's writing follows an ontology and epistemology of holism that advocates the use of what may be termed non-rational intelligences ${ }^{3}$ (such as emotion, spirit, bodily, unconscious, and dream) and not only rationality in order to arrive at a more encompassing truth and greater human fulfilment. I further argue that he favours the relational, in other words, he sees the individual as part of a whole 
composed of others and otherness (humans, non-humans, including the divine or transcendental) all of which need to find a way to communicate and connect, and that these paradigms of knowledge, present in most of Couto's works, are very much a part of classical (traditional) African systems of thought. ${ }^{4}$ I further argue that these epistemes have similarities with Zen Buddhism, the philosophies of Emmanuel Lévinas, Luce Irigaray and some psychoanalytical precepts put forward by Carl Jung and Julia Kristeva and the writing of Clarice Lispector - and in so doing, I demonstrate that paradigms from different parts of the world share commonalities revealing that human beings from various cultural and saptio-temporal backgrounds are similar and find approximate ways to express their human 'lack' and yearning.

As a continuation of this previous transcultural comparative project, the current study aims to unearth some other similarities that exist between African classical knowledge systems, as put forward in the writing of Mia Couto and the work of other Africanists such as Wole Soyinka, Jacob Olupona and Léopold Senghor - in respect to their links to poetic speech and relational, holistic and mystical epistemologies - and the ideas defended by some western critics such as Mark Epstein, Gaston Bachelard, John Fox, and Thomas Greene in relation to the powers of poetic language (or art in general) and the search for knowledge, holism, and existential realisation. The central argument here is that poetry and creative writing have the function of powerful therapies, serving as tools that allow a holistic apprehension of life, and in that sense, are very much associated with African traditional ways of understanding self and universe. Thus, it is argued that both of these processes serve to disrupt human fragmentation and temporarily (or symbolically) suspend the 'lack' (incompletion and loneliness) that most (if not all) humans are bound to feel. This again serves to show that humans from different socio-cultural and temporal spaces may in fact share more than what we may be inclined to accept and come up with similar ways to ease existential distresses and deal with fundamental ontological questions. Furthermore, one of my main objectives here is to argue that traditional African societies present good models of living as they offer, through their holistic practices, a 'healing' that modern societies tend to discard with their emphasis on secularism, minimisation of the invisible and metaphysical, and the privileging of unidimensional rational paradigms of knowledge which tend to lead to a loss of humanity and curb ontological realisation. As a springboard for these discussions, I will draw on the short story 'The boy who wrote verses' taken from Couto's collection O Fio das Missangas (The Beads Necklace) published in 2004 - though I will also refer to other works by the author.

Several Coutian critics have pointed out that Mia Couto's writing is often driven by a cultural agenda: he wants to give voice to and rescue the traditions of the many ethnic groups of Mozambique which do not follow the modern/urban paradigms of living that tend to characterise western epistemologies and which value individuality, materiality, control of the physical world by the human agent and a rational dissecting and utilitarian type of reason, while discarding or minimising mystical, religious or relational systems of knowledge. These western systems first came to Mozambique with the Portuguese colonisation in the $16^{\text {th }}$ century and were then reinforced by the post-independence Marxist Frelimo government and again in the early 1990s, with the move toward democracy and neoliberalism by a plethora of western (or lately Indian and Chinese) development agencies (such as non-governmental organisations, NGOs) or investors which came to 'save' and modernise the country. There is in the $16^{\text {th }}$ century in Europe a movement 
from a theocentric world view where God is seen as dominating humans to a humancentric view where humans become like 'gods' and think themselves capable of understanding and controlling the world. ${ }^{5}$

In the words of Sheryl Sterling (and taking after Sylvia Wynter's definition of the 'new Man' of the Age of Discovery):

In Western man's exploration and cognitive remapping of the world, as evident in the voyages of exploration and the development of the physical sciences, Wynter shows, he defines himself as the other of God, instead of his subordinate as promoted in the Judeo-Christian tradition. Conceptually, with this definition of himself as Man, the earthly avatar of God, and the center of creation and agency, he could not conceive of the peoples 'discovered' in these voyages as anything, but other to himself. Since Euro-man invents himself as the archetypal standard and model of humanity, these others are not quite human or even the same type of human, and as Wynter further argues, it results in our present struggles with respect to race, class, gender, sexual orientation, ethnicity, struggles over the environment, and the sharply unequal distribution of the earth's resources. (2015: 126)

This hubristic European and universal 'man' sees himself as the replacement for God ('the other of God' as Sterling notes above), a being whose duty is to bring civilisation to other 'lesser' people who are not entirely human and who need the Eurocentric civilisation to save themselves from primitivism, disorder, mysticism, irrationality and base materiality. Couto wants to write against this (hubristic) invasion of foreign values. He writes against this 'new Man' with the intent to recover or reconstruct the Mozambican pre-colonial cultural landscape and portray Mozambicans as full people (not 'others' of the Europeans), a people who does not necessarily need to be civilised and has a cultural system and way of life that is powerful, valuable and brings great fulfilment by presenting life in a holistic fashion where humans are linked to others (the humans) and the otherness (the non-human and the transcendental) and where rationality and science are not the only prisms through which to engage with the world and can in fact curb human existential realisation and bring much unhappiness.

Referring to Mia Couto's literary agenda, David Brookshaw notes:

At the moment, his critique is directed against that which we could designate the cultural amnesia of the Mozambican urban social and political elite, in other words, the increasing gulf between the majority of Mozambicans who interpret the world using traditional systems of knowledge (or modified traditions given that Mia Couto's creative universe is undergoing a continuous process of adaptation and re-invention) and a materially wealthier urban population, which in one way or another has distanced itself from those traditions and seems to favor only the knowledge system that permits the accumulation of more and more economic and social power. Mia Couto tries to explain the world according to those who are not given the chance to voice their ways, those who have been left behind by history, voices that compose the ethnic minorities of the country. $(2008: 130)^{6}$

In order to oppose the westerncentric episteme that dominates Mozambique, Couto's privileges the use of poetic language and speech and has often referred to himself as someone who tells stories via the medium of poetry and writes prose poetry. ${ }^{7}$ The power of poetry and creative speech and the need to satisfy the individual creative call to attain full beingness are revealed in 'The boy who wrote verses'. The boy possesses in him the creative call, the yearning to get out of the mundane, the neatly organised, the language that 'does not speak' in its full capacity, that divides and imprisons reality 
in finite paradigms, the language that has lost its magic, its 'divine vocation' and no longer 'produces enchantment' to recall Couto's words in the quotation used above. The boy's creative call is constantly suppressed by the society he lives in, a society that has forgotten how to create, how to allow the non-rational intelligences to come forward and inform the understanding of self, world and universe, how to enter relational and holistic apprehensions of life, all of which are fundamental parts of traditional Mozambican knowledge systems. These holistic and relational systems privilege intelligences like emotion, spirit, instinct, the mythical and the mystical and do not rely solely on rationalistic insights that tend to compartmentalise and look at reality from a finite angle, which, in its eagerness to understand and classify everything in scientific ways (which often follow an unreflective anthropomorphic lens that aims to control through finalised knowledge) disfavours or completely drops mystical dimension of life apprehension. The latter (Eurocentric) paradigm also tends to incorporate otherness into sameness given that it follows paradigms of knowledge that presents itself as universal, therefore alienating difference and restricting the window through which knowledge, advancement and human potential can be realised.

In the story 'The boy who wrote verses' we can clearly detect Couto's agenda of trying to rescue the traditional Mozambican epistemologies, and in so doing, giving voice to the majority of Mozambicans. There is in the story a desire to reconnect with what I have termed the 'Mozambican choric self' (Marques 2011) (the pre-colonial and more traditional Mozambique) and its mystical, spiritual and relational epistemologies and ontologies that privilege multiple cognitions and intelligences like emotion, spirit, dream and ambivalence and where the $I$ is seen as connected with all the others and otherness (the non-human or the transcendental). We see in the story a rejection of purely rational (modern) cognitions that dissect, divide, impose single meanings/interpretations and curb human ontological realisation and the drive toward creation. The story brings to the forefront the importance of wonder, dream and magic - ways that permit consciousness expansion, greater fulfilment, happiness, and overall psychological health - while pointing to the importance of poetic language in that process. In this narrative, we have a boy who writes verses, and because of that, he is shunned by his family and community. They see the boy as being abnormal, as having a disease that needs to be cured by a doctor:

- He writes verses!

She pointed at her son as if handing over a criminal to the police. The doctor raised his eyes, above the lenses, with the effort of an alpinist on top of a mountain.

- Is there a history in the family?

- I am sorry doctor?

The doctor explained. Dona Serafina gave all the details, saying that no, there was no history. The child's father, a mechanic by birth and lazy by destiny, never peeked at a page. He read engines, interpreted steel plates. He treated her well, had never beaten her, but the most delicate sweetness that she had gotten from him was on their nuptial night. (Couto 2004: 133)

Like the father of the boy who reads plates and engines, the doctor is a man of technology and science: both read reality using medical, scientific and technological 
paradigms based on the closed (inflexible) theories of the grand dame of knowledge that science claims to be. Neither of them shows affection (passion) for their profession and both display a sense of superiority about their understanding of the world. They have both lost the capacity to think outside of the scientific, unidimensional prisms of knowledge associated with modernity; they are not playful and appear as detached, matter of fact beings whose gentleness is dormant. The mother of the boy misses the gentleness (the caresses) of her husband - she misses the nuptial night when she received some tenderness from him, which actually resulted in the conception of the son/this son-poet, but she does not complain and follows the husband's ways as she has little power to change the situation. The boy, considered to have a disease, is taken to the doctor, the societal figure associated with science, reason, lucidity and clear answers: the entity that is valued in a world that believes in medications to cure madness. But the madness cannot be cured with medications because the madness is a madness of the soul and that is why the boy writes verses, as a sort of self-therapy, to understand himself and the world and universe around him, to rescue magic and find enchantment, an enchantment that his world discards, sees as useless, as superstition even - old knowledge which we no longer should believe in:

- Are you hurting?

- It is life that is hurting in me.

- What do you do when you are assaulted by those pains?

- The best I know how to do Excellency.

- And what's that?

- I dream.

The doctor found the boy strange. It was hard to believe, given his age. But the boy, in a timid voice, explained himself slowly. He said that he, modesty aside, had invented dreams that are no longer alive today, those found only in the old days, things that shouted at the earth. And he added he could provide examples so that the doctor would believe in what he was saying. But the doctor interrupted:

- I have no time boy, this is not a psychiatric clinic. (Couto 2004: 134-5)

The doctor has no time for poetry or dreams and thinks that people who write or dream are sick and need to go to a psychiatric hospital. Yet after reading some of the boy's poems, at the insistence of the mother, the doctor changes his mind. Recognising his own need for therapy, he informs the mother that the boy's disease was indeed a grave one and offered to have him admitted to his own clinic and pay for all the expenses during the stay. The irony and twist of the story is that the doctor, a man of science and reason, finds in the boy's poems a cure for himself, for from the moment that the boy is admitted, the doctor stops attending to his own clients and is almost always in the boy's room, listening to his words and asking for more, like a hungry soul, who had found the true medication for life, his own life - a medication he had discarded before, 
having replaced it with science and pharmaceutical drugs. The doctor is now the patient and the boy is the doctor:

Today whoever visits the doctor's office rarely finds the doctor. He sits, mornings and afternoons, in a corner of the room where the boy is interned. Those passing by can listen to the paced voice of the mechanic's son, who reads, verse by verse, his own heart. And the doctor trying to shorten the silences: Don't stop, my son. Keep reading ... (Couto 2004: 136)

The fact that the doctor is wanting to shorten the silences here also signifies that he is not yet able to connect to the world the boy is trying to connect with through poetry; he cannot yet understand that silence is an important part of poetry for it permits one to ponder upon which words to use, it is the space that allows us to rethink language and come up with novel (deeper and better) ways of saying reality, reinventing reality, thus revealing the world anew to us. Silence can also be an indication that words are in fact insufficient and just a translation for that which cannot ultimately be told in language: silence is a way for us to get out of language and recapture (imagine/envisage) the world in its purity before it was adulterated by language which is just a technology that we use to communicate and try and understand the world and the universe, a system that in fact creates and constructs us and reality through limiting socio-political categories that imprison us and restrict our beingness and freedoms, and tame our personhood. Moreover, the presence of silence also alludes to the multiplicity of meanings that poetic language allows for. In this very multiplicity we sense an uncertainty about the very power and capacity of words: words can mean this or that because the ultimate reality of the world and the cosmos is inaccessible to us and therefore we play with words in an attempt to unveil this mystery. Poetic words, in their fragility and uncertainty, their silences, their naming and un-naming of reality, allow for the possibility of multiple realities and understandings thus becoming the magical vehicle to connect us with a mysterious, complex and ultimately untameable reality, a world that can only be envisaged (sensed) through non-rational prisms, the eye of the spirit, so to speak. The doctor is too westernised, urbanised, fractured and distanced from the local Mozambican traditions and has allowed reason to become his main paradigm of cognition. Perhaps with more exposure to the boy's remedy, he can arrive at an understanding of the power of silence, its actual connection to poetry - see it as a tongue to speak with the otherness, including the dead ancestors, and even a method to suspend the notion of split time (past, present and future), entering a time that is 'whole', undivided, unmediated by rational thought and language, a time that steps away from the mechanisation and fragmentation that is very much a part of the highly industrialised and technological modern world. In Couto's own words:

[I]n rural parts of Mozambique the notion of nonlinear time is still dominant. For them, the past has not passed.... In the community where I was born and still live, silence is not seen as an absence. Rather, if a group of people are chatting, silence is something that suddenly appears. If that happens in Europe it immediately causes uneasiness. The fear of emptiness emerges, and someone will say whatever pops into his head to cover it up. In Mozambique, silences are also part of the conversation, but people are not afraid of sharing those instants. Because silence, for them, is not an absence, it's when the dead and the lost are communicating with us. Since my childhood I have learned not to fear silence, and to listen for voices and music that can only be expressed by the absence of words. ${ }^{8}$ 
When asked by the doctor if he still writes, the boy points to his notebook and responds, 'This thing that I do, doctor, is not writing. What I am doing is living. I have this piece of life, almost at midpoint' (Couto 2004: 135). Writing is equated with living, it is a way to attain fulfilment by tapping into our creative energy, connecting to all the others and otherness out there (human, non-human and transcendental), it is a way to see, feel and understand how we are part of that otherness; it is a way to constantly converse with all that surrounds us and inquire about existence, a way to try and resolve the enigma that life is, that being is, or even a way to suspend the 'lack' that we, as existential beings, are bound to feel. Writing (especially poetic and literary writing), like art in general, is a way to temporarily and symbolically erase selfhood, enter wholeness of being and feeling and experience consciousness expansion. It constitutes a letting go of the individual ego/self, which tends to always feel imperfect, incomplete, always in a state of yearning, missing something, someone, mourning a lost (imagined) state of perfection and completion. As illustrated by Epstein:

We are all haunted by the lost perfection of the ego that contained everything, and we measure ourselves and our lovers against this standard. We search for a replica in external satisfactions, in food, comfort, sex, or success, but gradually learn, through the process of sublimation, that the best approximation of that lost feeling comes from creative acts that evoke states of being in which self-consciousness is temporarily relinquished. These are the states in which the artist, writer, scientist, or musician, like Freud's da Vinci, dissolves into the act of creation. (1995: 81-2)

Creative writing, especially poetic, lyrical writing that uses complex and novel ways to express human realities and perceptions, is considered a powerful medicine, a sacred method that heals, integrating the disjointed, creating a symbolic merging with all and everything and therefore easing the lack that we feel. This type of writing makes sense of the senseless, grounding us to a holistic beingness that feeds our multiple dimensions (physical, emotional, intellectual and spiritual) making us feel less fragmented and lonely, less far from the perfect state that we yearn for. In Poetic Medicine: The Healing Art of PoemMaking, Fox tells us:

Poetry is a natural medicine; it's like a homeopathic tincture derived from the stuff of life itself - your experience. Poems distill experience into essentials. Our personal experiences touch the common ground we share with others. The exciting part of this process is that poetry helps people integrate the disparate, even fragmented parts of their life. Poetic essences of sound, metaphor, image, feeling and rhythm act as remedies that can elegantly strengthen our whole system: - physical, mental and spiritual. (1997: 3$)^{9}$

This description of the healing powers of poetry (as something that 'strengthen[s] our whole system: - physical, mental and spiritual' as Fox puts it) is in fact remarkably close to the holistic and spiritual apprehension of life that traditional African societies tend to follow. This holistic and spiritual ethos is often attained (symbolically recreated or enacted) through religious rituals that merge different arts such as dance, music, poetic language and resort to colour (the visual) or the use of masks - all of which are tied to a certain cosmogony (a story of creation) and the non-separation between the sacred and the secular, which allow entrance into the mystical realm where human and nonhuman, self and other, human and divinity, visible and invisible, living and dead merge into a 'whole' and one (symbolically) enters what could be termed as the expanded and 
relational self. In this African traditional religious and sacred space, art, including creative speech (poetry) is capable of making things happen, of healing the broken, of joining the dissected. Olupona notes:

As there is no strict separation between the sacred and the secular in traditional African cultures, it follows that arts and material culture are influenced by religious practices and traditions. Using the word 'art' in an African context can have confusing and unintended consequences. In the west, art is now often understood to exist for its own sake. This is a departure from the standard prior to the twentieth century, in which art typically had religious devotional aims. (2014: 72)

The significance of orality and speech in Africa can be seen in the many words that diverse cultural groups use to describe a wise or intelligent person. For the Limba and the Burundi, a person is clever if he or she uses speech well. Most African societies praise singers who recite not only a person's lineage but also the achievement of that lineage or clan. Words hold power. This performative aspect of African societies becomes even more pronounced in religious practice. Epic tales, songs for the deities, praise poetry, incantations, and recitation of divination verses are all examples of this rich verbal art. According to the Dinka of Sudan, 'a person's creative speech is ... an integral part of his ethos or personality'. Words have the power to bring things into being and imbue them with life. (2014: 83)

And as Soyinka has put it in 'Drama and the African world view', African art (in this case drama, or what he calls ritualistic theatre) enacts a cosmogony and a worldview and each aspect of the dramatic performance is important in that exercise: the visual, the sensorial, the aural, and the performative. The aim is to enact this cosmogony with such perfection and mastery that the audience goes into a trance state, experiencing a mystical holistic consciousness, entering the spiritual world, and merging with all reality, therefore symbolically exiting the individual self. In addition, and as Soyinka notes, it is important to note that this type of ritualistic theatre, which was also the norm in ancient Greece - though Europe has come to distance itself from that tradition - is a medium used by humans to exercise control over an unknown and immense universe, allowing a connection with the metaphysical, a communicating with an immensity beyond our immediate grasp or understanding, and in that very process, appease existential fear and anguish. In Soyinka's own words:

I would like to go a little deeper into this ritualistic sense of space since it is so intimately linked with the comprehensive world-view of the society that gave it birth. We shall treat it first as a medium in the communicative sense and, like any other medium, it is one that is best defined through the process of interruption. In theatrical terms, this interruption is effected principally by the human apparatus. Sound, light, motion, even smell, can all be used just as validly to define space, and ritual theatre uses all these instruments of definition to control and render concrete, to parallel (this is perhaps the best description of the process) the experiences or intuitions of man in that far more disturbing environment which he defines variously as void, emptiness or infinity. The concern of ritual theatre in this process of spatial definition which precedes, as we shall discover, the actual enactment must therefore be seen as an integral part of man's constant efforts to master the immensity of the Cosmos with his minuscule self. The actual events which make up the enactment are themselves in ritual theatre, a materialisation of this basic adventure of man's metaphysical self. (1978: 39-40)

Ritual theatre, let it be recalled, establishes the spatial medium not merely as a physical area for simulated events but as a manageable contraction of the cosmic envelope within which 
man - no matter how deeply buried such a consciousness has latterly become - fearfully exists. (1978: 41)

Couto has himself told us about the link between his writing and the traditional Mozambican epistemologies, the link between poetry, performance, dance and entrance into the mystical realm - and how he came to write the way he does to capture the Mozambican traditional ways:

I was in Inhambane and there I was told a legend related to the whales. It would be very interesting to tell that story, to fictionalize that legend. I was with a group of friends who encouraged me: 'Write a story!' And I wrote a story. And, as I was writing it, I realized that I could not use the classical Portuguese, the standard Portuguese in order to tell the story with all the poetic charge it had. It was necessary to recreate a language that would bring forward that ambiance of magic in which the story had been told to me. And so I started that experience, and, interestingly, I was suddenly transported to my childhood, transported to the moments I told you about, when the elders were telling me stories. At that moment when they were telling me the story there was something religious, a feeling of fascination, of magic, and suddenly the world ceased to exist and those individuals were transformed into gods. It was impossible for you not to believe, for you not to be completely present and imprisoned in that fantasy that they were creating. It is important to understand how these storytellers functioned. Now they barely exist, there are very few of them, they are old. But they tell stories in the complete sense, they do all the theatre: they sing, dance ... And I thought: it would be necessary to transport this magical ambiance created by these storytellers to the writing domain, to the domain of paper. And that is only possible through, one, the use of poetry, and two, the use of a language that utilizes this game of dance and theatre that they were making. So it was there that I started, in fact, to experiment the limits of language itself and to transgress with the intent of creating a space of magic. (Quoted in Labin 1998: 1015-6)

As I argue at length in Transnational Discourses on Class, Gender, and Cultural Identity (chapter 1 ) in relation to the collection of short stories Contos do Nascer da Terra, Couto uses poetry and its methods to penetrate the 'Mozambican choric self', which represents the traditional Mozambican epistemologies - cognitions that modern Mozambique discards and which have a holistic, mystical and inter-relational dimension and like poetry favour spiritual, sensorial, emotional and animist paradigms of understanding. I further argue that this choric self/chora is in some ways similar to the Kristevan symbolic chora, the non-self or the pre-self which contains in itself all the potentiality of life, of being, where the self is not divided but united in a wholeness. Kristeva calls this the 'abject' noting that images of shit, blood, mud and the mother's womb, where child and mother are one, can symbolise this wholeness, this integration. ${ }^{10}$ Artists try to recreate this 'wholeness' through art, symbolically dwelling in a totality where nothing is missing, where one feels whole and our 'lack', 'the perfection of the ego that contained everything' as Epstein notes above, is temporarily erased and we feel 'at home', immersed in the otherness that is all around us, thus becoming whole and complete. I am arguing here then that the Mozambican traditional epistemologies recreate and represent this wholeness, this completion, which modern and western societies, having departed from the religious and sacred realm and compartmentalised life, no longer can access, except via art (and I must add, a certain type of art) when individual selfhood is erased (suspended) and the I merges with the otherness/every-thingness, becoming grander, perfect, fulfilled. ${ }^{11}$ 
In Poetry, Signs, and Magic Greene opines also that humans have, throughout history, been pushed towards writing poetry (or even making art) because they 'lack' and poetry, with its incantatory and magic capabilities can create a feeling of possession, control, a wholeness even that appeases our insufficiency. Poets are (special and sensible) beings who are able to tap into the energy of the universe and bring it forward through a special type of language, a magic language that tells of a reality that may be beyond our full comprehension but which we know exists and with which we need to find ways to connect to, to satisfy our yearning to understand that which surpasses us and also to feel part of it. Poets are shamans of sorts who are able to recall, through their metaphoric language, a language imbued with mystery, energy and magic which generates awe, the forces beyond us, those realities that we ache to connect with and understand in order to access the 'whole'. As Greene puts it:

The persistence of magic, the nostalgia for magic, the dangerous returns of suppressed magic, betray what looks like a perennial desire for signs endowed with potency in themselves.... These are signs that carry their energy with them, though in some ways the energy can only be tapped by specially gifted individuals. In the verbal gestures of poetry that has detached itself from its putative origins, we can discern the vestigial gestures of the shaman, as Picasso discerned analogous gestures in painting. Una pictura poesis. [This] might suggest that we continue to be afflicted by the sensation of lack that confronted our earliest ancestors. (2005: 45)

Being a poet and fiction writer, I too experience a wholeness, a perfection, a completion, or what I have termed 'God' when engaged in this artistic deed, a 'being in the zone', as some might call it. In a recent interview, I have put it this way:

[W]riting is a deeply spiritual and ontological experience for me so being seriously immersed in it feels like there is nothing missing, like I am with 'God'. And that 'God' is Good! It is as if you are dwelling in a totality, a wholeness, where there is nothing missing, because you are all and everything, you are many, you exit the smallness of your ego (you forget yourself) and become joined with the others and the otherness. You are no longer alone. You are communicating. Truly communicating. You are in communion. You are extended. Loving the world and the universe by becoming part of them, one with them. (Marques 2015)

Toni Morrison's quotation used at the beginning of this article echoes this same feeling of merging, communion, completion, insight and even control, and is in fact, as she also notes, like an out of body experience. Let us recall her words:

I left my body and I was only eyes and mind, that's all ... I could think and I could see. I didn't try to speak because I was so fascinated with this experience... The attraction! Ooh, it was better than anything I'd ever felt. It was free, it was intelligent and I was in control. And the only other time that happens - those three things - is when I write. ${ }^{12}$

The poet's sensitivities, metaphysical and daydreaming proclivity allow him/her to enter (or speak from) what Bachelard calls the 'intimate immensity' or a 'phenomenology of roundness', a certain innocent consciousness that permits us to see through the cognitions of the heart and soul rather than conscious thought and which favour a vision of reality that is 'round', where things appear as all related and interrelated, as part a whole. Within this cognitive space, the house becomes the universe, the particular leads us to the universal: one goes from the personal to the non-personal, from the self to 
the other, from the lonely self to a wholeness that fills (and fulfils), thus erasing our lack/our insufficiency. ${ }^{13}$ As Bachelard writes:

One might say that immensity is a philosophical category of daydream. Daydream undoubtedly feeds on all kinds of sights, but through a sort of natural inclination, it contemplates grandeur. And this contemplation produces an attitude that is so special, an inner state that is so unlike any other, that the daydream transports the dreamer outside the immediate world to a world that bears the mark of infinity. (1964: 182)

When metaphysicians speak briefly they can reach immediate truth, a truth that, in due course, would yield to proof. Metaphysicians, then, may be compared and associated with poets who, in a single verse, can lay bare a truth concerning inner man. (1964: 232)

The room where the boy is now reading and writing is a necessary space, away from the noise and ready-made concepts that society imposes; it is a location where he can get in touch with his unconscious, where the old knowledge, the non-national intelligences that speak through poetry, can be brought to the surface in a newly born language that stays away from clichés - a language that speaks the world anew, that brings magic and restores enchantment. Through his verses, the boy resuscitates the old epistemologies of his ancestors and the Mozambican cultures, bringing them to life, recreating them on the page and making them less of an endangered species. He 'shouts at the earth' (Couto 2004: 135) through his writing, speaking to it and making it speak, awakening it from its dormancy, a state forced upon it by the continued imposition and overvalue of external values - and in so doing, he feels he enters a sort of dwelling, a holistic consciousness, feeling part of the earth. He becomes the earth, the earth becomes him: brothers and sisters speaking in a newly reawakened language, enjoying a boundless connection - entering the round space that Bachelard speaks of, or the communion, the merging and out of body experience that Morrison and I experience when writing.

The epigraph placed at the beginning of the story, taken from the boy's verses, asks, 'What is the point of having a voice if people only understand me when I am silent? What is the point of waking up if what I live is less than what I dreamed?' The first question posed here hints again at the fact that silence is a way to connect with the ancestors. As noted previously, silence does not indicate absence of thought or wisdom or knowledge or create uneasiness as it might in the West but rather an awareness of a world out there that we are trying to communicate with, the world of the spirits and dead ancestors typical of the traditional Mozambican cultural ethos. The boy says people understand him only when he is silent because he is aware that the people of Mozambique want to connect with the ancestors: they want to regain the spiritual, the world of the invisible and holistic dimension of life that is part of their traditional epistemologies. The Mozambican people in fact yearn for that connection and therefore they appreciate silence for it is a language (a way) to communicate with the metaphysical. Moreover, we can suggest that the voice the boy speaks with in his poems is like silence because in poetry words lose stable meaning and force us to constantly look for alternate and multiple interpretations of reality - in poetry we get lost in the plurality of possibilities presented to us through the unstable signifiers, and keep running after a meaning that is always evading us: we are like a dog trying to catch its tail. This plurality signals that language may in fact then just be noise for it never allows total and accurate access to reality: one ought to be silent then and 'read/ see' between the lines as the Brazilian writer Lispector (1973) has put it in Água Viva. 
And, as previously noted, silence denotes the incapacity of the word to tell reality and the space (the pause) that allows one to rethink language so that it can better tell the reality: it allows us to come up with better metaphors that can hint (recall somehow) the mystery of reality. Through silence and poetry (or in the silence that poetry evokes), we enter the creative, tapping into the energy of the universe and stepping away from ready-made language and concepts to access a freedom of thought that allows us to reconfigure and see the world anew, envisage a reality not imprisoned in the socio-politicality that restrains and chains us all, making us small beings and curbing our existential yearning that demands a connection to the mysterious non-self, to all that exists beyond us. When inside this poetic mode, this awareness, this consciousness, we capture the mystery, the magic and the energy of the universe, becoming shamans of sorts, as Fox notes above. It is this game, of catch me if you can that makes the act of writing and reading poetry worthy. Poetry creates awe and wonder in people by connecting them with the immensity of a universe that they cannot rationally know but have an awareness of and a need to communicate with as per the Mozambican traditional knowledge systems, which are now discarded (or greatly minimised) in Mozambique with the adoption of modern exogenic epistemes. The people hear the boy when he speaks like this because his words remind them of all life, all mystery, all wonder, a way of feeling and being in the world that they have dormant in them and which is now called up by the boy's poetic language.

If the boy were to speak like everyone else, the Mozambican people would not really learn anything: they would hear him but not really see into the vastness of their existence, they would not tap into the forgotten Mozambican epistemologies that value and demand wholeness, relationality and connection with the non-self, extension of the self beyond itself, that is. It is worth noting the use of the word (verb) 'entender' (understand, comprehend, grasp the meaning of, see into something) in the noted epigraph in the original Portuguese: 'De que vale ter voz se só quando não falo é que me entendem?' The word derives from the Latin intendere and it denotes the idea that we have to pay attention to get meaning out of something: we hear/see/experience something and we have to process it with all the wisdoms (intelligences) we possess, so to speak, to really comprehend the message being transmitted. From what is being said to us (or not said since the boy is referring to silence here and all its connotations as discussed above) we have to arrive at a meaning: what is being said does not constitute meaning itself. In order to arrive at comprehension, the message needs to be processed by us (the receivers of the message) on multiple levels: we have to be open to its energy with all our intelligences and cognitions, not just cerebral reasoning. In that sense, we speculate, we make cognitive connections; we tap into multiple ways of arriving at knowledge in order to get a better and more expanded comprehension of the message. The self then is the conductor through which the initial message passes but this very passing transforms the message due to the abilities (cognitive awareness) of the conductor: his/her capacity to create and arrive at meaning by allowing information from different sources to come in. The verb 'entender' in fact also means 'estender' (to extend, to spread) again suggesting that we go from that initial word (or situation) and we infer meaning/s. To 'entender' then is to understand beyond what is being stated, beyond the situation we have, beyond what we see: it is to feed off an energy that is there but which demands individual effort, a tapping into our own 
creative self and multiple cognitions to arrive at full comprehension. This tapping into the creative self also signifies that we humans possess in us a powerful call to expand beyond ourselves, to exit our lonely self and connect with a larger reality out there, a call to understand how it is that we are part of all that exists out there. Our creative energy is in fact a sort of cry of loneliness, a reminder of how much we lack, how much we are incomplete: it is a pain that demands to be appeased, lulled, and we do so symbolically through art, a medium that allows us to feel momentarily connected with the others and otherness in order to feel less alone, less fragmented and attain wholeness as Epstein notes. This is why the boy says to the doctor that his writing, 'this thing' that he does is not writing but living. Writing signifies living fully, wholly, symbolically suspending the 'lack' as discussed earlier.

The secondary meaning of the verb 'entender' ('estender') also points to another important aspect of Couto's writing: the self is a part of all there is out there and it feels the need to connect with (and understand somehow) that wholeness to feel more complete and realise its relational existential call. The self yearns to get out of itself: it wants to expand and spread itself to become a part of all its other parts, to enter/re-enter 'the lost perfection of the ego that contained everything' in the way noted by Epstein above. In his definition of African personality, Senghor has put it this way: 'Our subject abandons his I to sympathize and identify himself with the THOU. He dies to himself to be reborn in the Other. He does not assimilate, he is assimilated. He does not kill the other life, he strengthens his own life through it' (1965: 32).

For Senghor the getting out the self and the merging and relating with the 'THOU' (the other and otherness) is an act of love for the self and the non-self, the recognition that all things and beings belong to an interrelated 'whole' and thus the human self should not see itself as superior or even capable of fully and rationally comprehending the nonself. This merging with the 'Other/THOU' makes the human self grander, fulfilling the ontological desire to exit the self, thus appeasing the 'lack'. Such ontological posture differs from the typical European anthropomorphic paradigm, which as Senghor notes, tends to incorporate otherness into self (through the use of factual, rational and dissecting reason that discards alternative ways of understanding reality) thus killing, assimilating and destroying all that is non-human:

He [the European] first distinguishes the object from himself. He keeps it at a distance. He freezes it out of time and, in a way, out of space. He fixes it, he kills it. With his precision instruments he dissects it in a pitiless factual analysis. As a scientist, yet at the same time prompted by practical considerations, the European makes use of the Other that he has killed in this way for his practical ends. He makes a means of it. With a centripetal movement he assimilates it. He destroys it by devouring it. (1965: 29)

The many meanings implied in the verb 'entender' as explored here then mimic Couto's overall preoccupation in rescuing and understanding the traditional Mozambican epistemologies of relationality and holism. Couto's creative writing is a way to 'entender' and 'estender' and so is the boy's writing. This writing in fact functions like Soyinka's ritualistic theatre:

[it] establishes the spatial medium not merely as a physical area for simulated events but as a manageable contraction of the cosmic envelope within which man - no matter how deeply buried such a consciousness has latterly become - fearfully exists. (1978: 41) 
Both artistic practices (writing and theatre) create a symbolic space (on earth) that brings together all the creative forces, all life (all selves, other and otherness) to the page, to the stage, allowing humans to contract the 'cosmic envelope', ${ }^{14}$ thus momentarily inhabiting it and appeasing the existential lack. They both constitute sublimation processes.

The boy's poetic voice speaks of dreams, possibilities, endless ones, things not imprisoned in objective language and systems of thought that claim to know in order to control that which is in fact not fully knowable, cannot be fully understood: it speaks of the connection between all things, that roundness of the universe that Bachelard refers to or the 'cosmic envelope', as previously noted. The boy further says his dreams are grander than the reality that he sees when he wakes up because the dreams are in touch with the unconscious and can tap into the unknown, the hidden, that which is accessible through the eye of spirit, so to speak, and allow communication with the transcendental, the otherness that is beyond the visible realm - communication with the world of the dead and the ancestors, which is very much a part of traditional African religious paradigms. ${ }^{15}$ Dreams symbolise the envisaging of a reality, a way of being and seeing beyond the immediate world and allow for an expansion of beingness (an 'entender' and 'estender'). Through this poetic outlook vis-à-vis life, the boy defies the closed, cannibalistic, finite, materially based and scientific paradigms that modern and urban Mozambican elites are enamoured with, paradigms that see reality through an isolated and insufficient prism of cognition that claims full comprehension, attempting to impose universal systems of knowledge that discard complexity, diversity, otherness, infinity, and mystical apprehensions of reality, and see humans as the supreme rulers ('the others of God', to recall Sterling's words) of a closed and knowable universe. As Couto has indicated:

\footnotetext{
Science is an answer, not the answer ... [T] he only advice is this: to listen. We must again pay attention to the voices that we have been encouraged to stop listening. Let's make those voices visible. Let's maintain alive that capacity that we once possessed in our infancy and that made us revel in the marvelous.... The land where I was born and live - Mozambique - is a poor country and only a small group of people has access to that which we call science. But there are, in the rural areas, people who, even though illiterate, are wise. I learn a lot with those men and women who possess another type of knowledge and who are capable of solving problems using another logic for which my brain was not trained. This rural world, distanced from the scientific compendiums, has no less wisdom than the urban world where we live.... School often 'advises' us to look at the world through one window only and we close ourselves off to other truths. We become poorer, going deeper into our isolation. (2005: 48-9)
}

The story presents the poet (the artist) as the saviour of society. Given that the story concentrates on several professions (medicine, car mechanics and poetry), it also seems to be calling for the need to value inter-disciplinary study: different professionals work toward the ideal of finding a cure for the countless ills of humanity - or at least conjure some remedy that can appease human suffering and make us see the world and ourselves from multiple angles, bringing about consciousness expansion. In fact, for Couto science is also an art that searches for answers, an art that should go beyond the inflexible and finite paradigms that it often imposes itself:

I am a writer and a scientist [Biologist]. I see these two activities, writing and science, as being neighbours and as completing one another. Science is born out of inquietude, out of the 
desire to know beyond the limits. Writing is a false quietude, the capacity to feel without limits. Both are a result of a standing that rejects frontiers, both are a step dreamed beyond the horizon. For me Biology is not only a scientific discipline but also a story to enchant, the story of the epopee which is life. That is what I ask from science: that it makes me fall in love. And I ask the same from literature. (2005: 45)

I do not deserve trust because I lack the belief, that faith that must be the support of a scientist. I am a biologist but I do not live in Biology. I am merely a visitor in Biology, my soul wanders in the literary domains. (2005: 113)

Couto's ultimate appeal in the story 'The boy who wrote verses' and much of his other writing, seems to be that we must allow the poet (read also artist) to become the doctor, and in doing so, allow ourselves to dwell in an immensity that we may not fully comprehend but which constantly calls us. We must allow ourselves to be brothers and sisters of the universe, 'strive to understand and share the language of the trees, the silences and codes of the stones and the stars' and 'become better companions to those living and non-living creatures with whom we share the universe' (Couto 2005:48-9). The connection to that immensity, that wholeness, those relations with the others and otherness allow us to fulfil and expand our beingness, feed our ontological call that always asks for more, and in the process, suspend, or at least ease, our 'lack'. Couto's message then is also that we ought to learn from Mozambican paradigms of knowledge and that the 'old' ways of cognition that preceded the technological and scientific rationalism associated with European enlightenment (also valued and followed in Europe until then) have something powerful to teach us, to give us - and must therefore be rescued and nourished in our present times. Because we still suffer from the same disease of the soul, the same incompletion, the same 'lack', the same incapacity to understand a reality that surpasses us, continuously yearning to connect with a universe that insists in staying away from our full grasp. As David Levy notes in Scrolling Forward: Making Sense of Documents in the Digital Age, when examining the modern obsession with technology and information, and the importance of the written word:

We may not be able to predict the future, but in looking at documents we can perhaps see something at least as important: ourselves. For to look at our written forms is to see something of our striving for meaning and order, as well as the mechanism by which we continually create meaning and order. It is to see the anxiety within and behind this order. And it is also, potentially, to peek at that which lies beyond all formulations - 'the unimaginable universe' - not just as an object of fear and denial, but of wonder and celebration. (2001: 202)

Poetry, like technology (including the very invention of writing and language), like art in general, are tools that permit us to have some access to 'the unimaginable universe' that is out there. But it is a partial and incomplete access - and that is why we experience pleasure in this game of trying to know. What is fundamental not to forget here is that it is this continuous search that gives us pleasure, awe and enchantment, allowing our imagination to fill in the gaps, to conjure a reality beyond full rational comprehension. Were we to know everything fully, the magic and pleasure would disappear, the enchantment that little Aureliano Buendía felt in One Hundred Years of Solitude when he saw ice for the first time in the circus, would dissolve. To come full circle here let us recall Couto's words placed at the beginning of this article 'What moves me is the divine vocation of the word, which not only names but invents and produces enchantment.' To invent is 
to lie on one level - but it is also to tell a truth, a truth that we know is out there but which we cannot quite name.

\section{Notes}

1. Toni Morrison, interview with Pip Cummings, "'I didn't want to come back"': Toni Morrison on life, death and Desdemona', The Sydney Morning Herald 7 August $2015<$ http://www.smh.com. au/entertainment/i-didnt-want-to-come-back-toni-morrison-on-life-death-and-desdemona20150804-giqaxu.html\#ixzz3j0om24EA> (accessed 13 August 2015).

2. All translations pertaining to Couto's work, or other work in Portuguese, are my own.

3. I am borrowing the term from Hélène Cixous $(1975,1993)$ in her reference to écriture féminine. See La jeune née and Three Steps on the Ladder of Writing.

4. See Lebisa Teffo \& Abraham Roux (2003); Didier Kaphagawani \& Jeanette Malherbe (2003); and Léopold Senghor $(1965,2007)$.

5. This is not to say of course that within the western traditions this has always been the case or that there is a monoculture that invariably privileges the rational and individualistic paradigm. The romantic poetry of English poets William Wordsworth and Samuel Taylor Coleridge, for instance, displays an animist worldview where all things (human and non-human) appear as interrelated and shown as having an essence/a life, thus moving away or questioning the scientific mindset of the European Enlightenment that divides, dissects and puts humans at the centre of the universe (see Lyrical Ballads: 1798 and 1800). In fact, the romantic, symbolist and modernist movements of the mid-late $18^{\text {th }}, 19^{\text {th }}$ and early $20^{\text {th }}$ centuries respectively all work against the so-called scientific mindset associated with the European Enlightenment. African and western epistemologies have therefore not always been distanced from one another and dichotomies of 'us' versus 'them' do not reflect the entire reality of these worlds. More importantly, African or western cultures are never homogeneous or mono-discursive, often displaying ambivalence, intersectionality and questioning or circumventing clear cut dichotomies.

6. See also Phillip Rothwell (2004) and Marques (2011: 13-54).

7. See 'Cover' in O Fio das Missangas; and Maya Jaggi, 'Mia Couto: "I am white and African. I like to unite contradictory worlds"', The Guardian 15 August 2015 <http://www.theguardian.com/ books/2015/aug/15/mia-couto-interview-i-am-white-and-african-i-like-to-unite-contradictoryworlds $>$ (accessed 17 August 2015).

8. Interview with Andrade Esposito, 'We are made of memories: A conversation with Mia Couto', Paris Review 2 May 2013 <http://www.theparisreview.org/blog/2013/05/02/we-are-made-ofmemories-a-conversation-with-mia-couto/> (accessed 12 November 2013).

9. Many others have pointed out to the powers of poetic and creative writing and use of unusual metaphorical language. See for example, José Eduardo Agualusa's recent chronicle, 'A cura pela palavra: A boa poesia acende clarões no cérebro', O Globo 29 July $2015<$ http:// oglobo.globo.com/cultura/a-cura-pela-palavra-16586606> (accessed 9 August 2015). Also see the piece by Juliet Henry, 'Shakespeare and Wordsworth boost the brain, new research reveals', The Telegraph 13 January $2013<$ http://www.telegraph.co.uk/news/science/sciencenews/9797617/Shakespeare-and-Wordsworth-boost-the-brain-new-research-reveals.html> (accessed 7 August 2015).

10. See Julia Kristeva (1980) and Dino Felluga (2011).

11. In my articles 'Spaces of magic: Couto's relational practices' (2016) \& 'The way/s of "poetry": The contracting and expanding self in the writing of Mia Couto' (2015b), I argue how in the story 'The three sisters' from the collection O Fio das Missangas we see this merging and wholeness through the display of what I call metaphors of junction and arrest and I draw comparisons between these metaphors and Zen Buddhist philosophy.

12. Interview with Pip Cummings (note 1 above).

13. This movement from the self, the small and the particular to the non-self or the cosmic infinity is again explored in detail in my analysis of 'The three sisters' (Marques 2015b, 2016). 
14. Sean Creaven has said the following on the concept of the 'cosmic envelope': '[T] he concept of cosmic envelope performs an identical function to the earlier God-concept - i.e. of denoting ultimate categorial reality, absolute spirit, cosmic ingredient, boundless binding force, pure dispositionality, and so on. It refers not simply to the totality of things, nor to the ultimate constituent of being, but to the energy or spirit that binds the differentiated structures of reality together as part of a cosmic whole. Since this force is ingredient in all the emergent forms of reality, and is the ultimate constituent of all being, it follows, according to Bhaskar, that it carries within itself the potential for everything that exists, everything that has existed, or will come into existence' (2010: 23).

15. See Anthony Shafton (2002: 17-33).

\section{Note on contributor}

Irene Marques is a bilingual writer (English and Portuguese) who teaches at the University of Toronto and Ryerson University, Canada. She holds a PhD in Comparative Literature, and Masters' degrees in French Literature and Comparative Literature and a Bachelor in Social Work. Between June 2007 and May 2008 she held a Mellon Post-Doctoral Research fellowship at the University of the Witwatersrand, South Africa, where she conducted research on early colonial encounters between African women and European men. The research for this article was conducted at the University of Toronto.

\section{References}

Bachelard, G. 1964. The Poetics of Space (M. Jolas, trans). New York: Orion Press.

Brookshaw, D. 2008. 'Indianos e o Índico: o pós-colonialismo transoceânico em O Outro Pé da Sereia'. Moçambique: das palavras escritas. Orgs. Margarida Calafate Ribeiro e Maria Paula Meneses. Porto: Edições Afrontamento.

Cixous, H. 1993. Three Steps on the Ladder of Writing (S. Cornell \& S. Sellers, trans). New York: Columbia University Press.

Cixous, H. \& Clément. C. 1975. La jeune née. Paris: Union générale d'éditions.

Couto, M. 1997. Contos do Nascer da Terra. Lisboa: Editorial Caminho.

Couto, M. 2004. O Fio das Missangas. Lisboa: Editorial Caminho.

Couto, M. 2005. Pensatempos. Lisboa: Editorial Caminho.

Couto, M. 2009. E se Obama fosse Africano? E outras intervenções. Lisboa: Editorial Caminho.

Creaven, S. 2010. Against the Spiritual Turn: Marxism, Realism and Critical Theory. London \& New York: Routledge.

Epstein, M. 1995. Thoughts without a Thinker: Psychotherapy from a Buddhist Perspective. New York: Basic Books.

Felluga, D. 2011. 'Modules on Kristeva: On the abejct', Introductory Guide to Critical Theory. Purdue University<https://www.cla.purdue.edu/english/theory/psychoanalysis/kristevaabject.html> (accessed 19 August 2015).

Fox, J. 1997. Poetic Medicine: The Healing Art of Poem-Making. New York: Tarcher.

García Márquez, G. 1970. One Hundred Years of Solitude (G. Rabassa, trans). London: J. Cape.

Greene, M.T. 2005. Poetry, Signs, and Magic. Newark: University of Delaware Press.

Kaphagawani, N.D. \& Malherbe, J.G. 2003. 'African epistemology', in P.H. Coetzee \& A.P.J. Roux (eds), The African Philosophy Reader. New York: Routledge.

Kristeva, J. 1980. Pouvoirs de l'horreur: Essai sur l'abjection. Paris: Éditions du Seuil.

Labin, M. (ed). 1998. Moçambique: Encontro Com Escritores vol III. Porto: Fundação Eng. António De Almeida.

Levy, M.D. 2001. Scrolling Forward: Making Sense of Documents in the Digital Age. New York: Arcade Publishers.

Lispector, C. 1973. Água Viva. Rio de Janeiro: Editora Artenova.

Marques, I. 2011. Transnational Discourses on Class, Gender and Cultural Identity. West Lafayette, IN: Purdue University Press. 
Marques, I. 2015a. 'Creative lifestyle' 23 July <http://creativelifestyleblog.com/irene-marquesinterview/> (accessed 16 August 2015).

Marques, I. 2015b. 'The way/s of "poetry": The contracting and expanding self in the writing of Mia Couto'. JALA 9(2): 75-111.

Marques, I. 2016. 'Spaces of magic: Couto's relational practices', in G. Hamilton \& D. Huddart (eds). A Companion to Mia Couto. Suffolk: James Currey.

Olupona, K.J. 2014. African Religions: A Very Short Introduction. New York: Oxford University Press.

Rothwell, P. 2004. A Postmodern Nationalist: Truth, Orality, and Gender in the Work of Mia Couto. Lewisburg: Bucknell UP.

Senghor, S.L. 1965. 'The African apprehension of reality'. Prose and Poetry (J. Reed \& C. Wake, selected and trans). London: Oxford University Press.

Senghor, S.L. 2007. 'Negritude: A humanism for the $20^{\text {th }}$ century', in A. Tejumola \& A. Quayson (eds), African Literature: An Anthology of Criticism and Theory. Malden, MA: Blackwell Publishing.

Shafton, A. 2002. 'Grandmother will come: Ancestor visitation dreams', Dream Singers: The African American Way with Dreams. New York: Wiley.

Soyinka, W. 1978. 'Drama, and the African world view'. Myth, Literature and the African World. Cambridge: Cambridge University Press.

Sterling, S. 2015. 'Race matters: Cosmopolitanism, Afropolitanism, and pan-Africanism via Edward Wilmot Blyden'. The Journal of Pan African Studies 8(1) <https://www.academia.edu/> (accessed 2 April).

Teffo, J.L. \& Roux, A.P.J. 2003. 'Themes in African metaphysics', in P.H. Coetzee \& A.P.J. Roux (eds), The African Philosophy Reader. New York: Routledge.

Wordsworth, W. \& Coleridge, S.T. 2008. Lyrical Ballads: 1798 and 1800, M. Gamer \& D. Porter (eds). Peterborough: Broadview Press. 